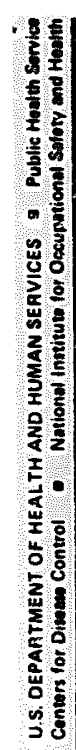




\section{PREFACE}

The Hazard Evaluations and Technical Assistance Branch of MIOSH concucts field investigations of possible health hazards in the workplace. These investigations are conducted under the authority of Section $20(a)(E)$ cf the Occupational Safety and Health Act of 1S7C, 2S U.S.C. 66S(a)(6) which authorizes the Secretary of Health and Human Services, following a written request from any employer or authorized representative of employees, to determine whether any substance normally found in the place of employment has potentially toxic effects in such concentrations as used or found.

The Hazard Evaluations and Technical Assistance Branch also provides, upon request, medical, nursing, and industrial hygiene technical and consultative assistance (TA) to Federal, state, and local agencies; labor; industry and other groups or individuals to control occupational heal th hazards and to prevent related trauma and disease.

Mention of company names or products does not constitute endorsement by the National Institute for Occupational Safety and Health. 


\section{SLMWARY}

On Decenber 13, 1983 the Naticial Institute for Occupational Safety and Health (HIOSH) recelved a request to evaluate diesel fume exposure in truck wells and areas where machinery is being noved at Pratt \& Whitney, East Hartford, Connecticut. Employees" concern centered on a "blue fume" which surrounds these areas which reportediy caused a variety of upper resfiratory and irritative symptoms.

Between February 2E - March 1, 1984, a NIOSH industrial hygienist and two medical officers conducted a site visit which included environmental ronitoring for carton nonoxide and the admintstration of medical questionnaires. Euvironmental sampling for carbon nonoxide was not indicative of overexposure during this visit (several short term, 3 minute, maximum exposures of $10 \mathrm{ppm}$ ). Yet, due to an unusual variability of production factors and recent layoffs at the flant, activity in these areas was acknowledged to be below the normal daily level.

To assess the health complaints, NICSH medical officers interviewed and completed medical questionnaires for seventy-six workers, which represented approximately one-fifth of the enployees in the selected departments. The questionnaires included an assessment of occupational rifstory, smoking status, upper and lower respiratory tract symptoms, eye and nose irritation, central nervous system effects, and factors regarding the work-relatedness of these symptoms.

Statistical analysis of the questionnaire data indicated that employees reporting exposure to diesel fumes experienced a significantiy greater percentage of respiratory symptoms than those not exposed. Individuals in Department 420, which is adjacent to one of the truck wells, but where methyl ethyl ketone (MEK) is the primary contaminant, had increased rates of cough, CNS symptoms and fatigue. Employees reporting exposure to MEK had significantly more respiratory and CNS symptoms, as well as headache and fatigue. Employees reforting exposure to cutting or grinding operations experienced irritative symptoms to a significantly higher degree than those not exposed to these operations.

Based on the results of this investigation, HICSH has determined that a potential health hazard did exist in that diesel emissions appear to be associated with a higher prevalence of respiratory symptoms in exposed workers both when analyzed by work area and by reported exposure to diesel] funes. Additionally, MEK exposure was associated with increases in CNS symptoms, headacie and fatigue. Recommendations are found in the body of this report to reduce these exposures.

Keyworas: SIC 3724, diese? fume, carbon monoxide, MEK. 


\section{INmoDucriax}

On December 13, 1983 the National Institute foz Occupational Safety and Health (NIOSH) received a request from employees of Pratt * hitney, East Hartford, Connecticut, to conduct a health hazard evaluation relative to diesel fume exposure in truck wells and areas where machinery is being moved. Employees concern centered on a "blue fume" which surrounds these areas, reportedly causing a variety of upper respiratory and irritative symptoms.

A site visit was conducted ca Febcuary 28-29, 1984 to conduct environmental sampling and employee meáical interviews.

\section{BACKGROUND}

Pratt \& Witney Aircraft Group manufactures aircraft engines at its" East Hartford location. Complaints about diesel fumes in the truck wells have been cause for concern for many years. Enviitomental monitoring of these truck wells was performed in Esbruary 1978 using the Emissions Analysis Laboraiory \#1 (EAL \#1). This portable laboratory is used extensively to measure the exhaust emissions from jet engines during manufacturing. This instrument provides a readout of the concentations of carbon monoxide, nitric oxide plus nitrogen dioxide (NOx) and total hydrocarbons. Results of measurements taken at times expected to produce the highest levels indicated short term (10-minute) peak exposure to 00 as high as $30 \mathrm{ppm}$. Total hydrocarbons peaked at 10 ppm, while NOx was fairly constant around 1 pgm.

Truck wells are not the only source of diesel funes. The upgrading of equipuent, and relocation of departments within the plant, often requires the movement of heavy machinery. If the equipment is too heavy for a forklift (usually gas or electric), diesel powered Caterpillars ar: employed to move the large machines.

\section{EVALUATION DESIGN AND METHOLS}

\section{A. Environmental}

Due to the low activity level within the plant during this survey, and the intermittent nature of diesel fume exposures, environmental monitoring was limited to direct reading carbon monoxide measurements as a relative indicator of the presence of diesel fumes. Carbon monoxide is the largest and most readily sampled contaminant in diesel fume, but is not soley responsible for adverse health effects resulting from exposure. Other contaminants that have been identified in diesel fume, but present to a much lesser degree include: oxides of nitrogen, aldehydes, phenols, hydrocarbons and sulfuric acid.

Direct reading carbon monoxide measurements were obtained, using an Ecolyzer $\mathbf{M 4}$, in various truck wells during loading and unloading operations. Adjacent areas were also spo: checked for peak 00 readings. 
Instantaneous readings were also cutained whenever visihle exhaust was observed from trucks within the building. Shidx: the activity level was minimal, NIOSA simulated the accumulation of diesal fume in a 23 minute test run of one of the Caterpiliars. The querator of the vehicle varied the throttle to simulate what would be expected while noving $a$ large piece of machinery.

The results of previous company sampling was reviewed, as well as work practices in the various truck wells. Euployses were interviewed to determine which work practices generally create diesel fume problens.

3. Medical

During the site visit, the NIOSH investigators conducted confidential, structured interviews with employees in a number of departax. The company safety department provided us with a list if all employees for the designated departients. We then arbitrarily selected approximately one-fifth of the workers from each department for interviewing.

The questionnaire included an assessment of occupational history, smoking status, symptons associated with diseases of the upper and lower respiratory tract, eye and nose irritation, the central nervous system (GNS) and factors regarding the work-relatedness of these symptoms.

We also received from the company a list of all OSHA recordable illnesses for 1983.

During the medical interviews, a number of other workplace exposures to process substances and health problans $x$ raised. Statistical analyses were performed relatiw reported exposures to wethyl ethyl ketone (MFK) ard ininding operations (in addition to diesel fumes).

MGK is used in Department 420 as a cleaning solvent to wipe down fan blades on turbine engines.

\section{EVALUATION CRITERIA}

As a guide to the evaluation of the hazards posed by workplace exposures, NIOSH field staff employ environmental criteria for assessment of a number of chemical and physical agents. These criteria are intended to suggest levels of exposure to which most workers may be exposed up to 10 hours per day, 40 hours per week for a working lifetime without experiencing adverse health effects. It is, however, important to note that not all workers will be protected from adverse health effects if their exposures are maintained below these levels. A small percentage may experience adverse health effects because of individual susceptibility, a pre-existing medical condition, and or a hypersensitivity (allergy). 
In addition, some hararcous substances may act in cambination with other workplace exposures, the general enviroment, or with medications or personal habits of the worker to produce health effects even if the occupational exposures are controlled at the level set by the evaluation criterion. These combined effects are often not considered in the evaluation criteria. Also, some substances are absorbed by direct contact with the skin and micous membranes, and thus notentially increase the overall exposure. Finally, evaluation critaria may change over the years as new information on the toxic efferts of an agent becomes available.

The primary sources of environmental evaluation criteria for the workplace are: 1) NIOSH Criteria Documents and recommendations, 2) the American Conference of Governmental Industrial iygienists' (ACGIH) Treshoid Limit Values (TLV's), and 3) The U.S. Department of Labor (OSHA) occupational health standards. Often, the NIOSH recomiendations and the ROGIH TLV's are lower 'than the corresponding CSHA standards because they are usually based \%: more recent information than the OSHA standards. The OSHA standards may also be required to take into account the feasibility of controlling exposures in various industries where the agerits are used.

The NIOSH-recommended standards, by contrast, are based soley on cuncerns relating to the prevention of occupational disease. In evaluating the exposure levels and the recommendations for reducing these levels found in this report, it should be noted that industry is legally required to meet only those levels specified in an CsiA standard.

A time-weighted average (IWA) exposure refers to the average airoorne concentration of a substance during a normal 8 to 10-hour workday. Some substances have recommended short term exposure limits or ceiling values which are intended to supplement the IWA where there are recognized toxic effects from high short term exposures.

Diesel fumes contain several individual chemicals which are the product of burning diesel fuel. The concentrations of these chemical are dependent on the completeness of combustion within the engine, and can be directly related to how well the equipment is maintained. Chemicals that have been identified in diesel exhanst, as well as the established exposure criteria are listed in the following table. 
Page - 5 -

\begin{tabular}{|c|c|c|c|}
\hline Pollutant & MOSH criteria & CstiA standard & АCHIH \\
\hline Carbon monoxide & $\begin{array}{l}35 \text { pqu ThA } \\
200 \text { pqu ceiling }\end{array}$ & 50 pgm 8-hr TWA & 50 pgan \\
\hline Hydrocarbo is & $\mathbf{N} / \mathbf{A}$ & $\mathbf{N} \mathbf{A}$ & $\mathbf{N} /$ \\
\hline Nitric oxide & 25 pgen Tin & 25 pqu 8-hr TwA & 25 pqu \\
\hline Nitrogen dioxide & 1 pqm 15-min & 5 ppan 8-hr $\operatorname{Tm}$ & 3 ppan \\
\hline Phenols & $5.2 \mathrm{ppm}$ Th & 5 pgm 8-hr ThM & 5 pgrm \\
\hline $\begin{array}{l}\text { Aldehydes } \\
\text { (as BCOH) }\end{array}$ & 1 ppm 30-min & 3 pgan 8-hr Tin & $1 \mathrm{pgm}$ \\
\hline ulfuric acid & $1 \mathrm{mg} / \mathrm{m}^{3} \mathrm{~T}$ & $1 \mathrm{mg} / \mathrm{m} 3 \mathrm{TNA}$ & $1 \mathrm{mg} / \mathrm{m}_{3}$ \\
\hline
\end{tabular}

Health effects

Symptoms of acute exposure to diesel fume affect primarily the respiratory system. Studies are ongoing witisin NIOSH and elsewhere to determine the effects of chronic exposure. However there is concern about the carcinogenic potential of some of the contaminants in diesel exhaust, as well as the symergistic effects of exposure in combination with other industrial pollutants.

For this study, NIOSH has analyzed the medical questionnaires according to several variables to determine if reported health effects are attributable to reported exposure to diesel fume.

VI. RHSULTS

Environmental

Carbon monoxide readings in truck wells 1, 2, \& 10 naver exceeded 10 pqu. Company data indicated levels as high as $30 \mathrm{pgm}$. It was acknowledged that there was a low level of activity during this NIOSH visit, but uncontrollable production factors were such that we arrived at a slow period.

The simulated operation of the Caterpillar produced $\infty$ levels which rose steadily for the first 9 minutes from 0 to $10 \mathrm{ppm}$. The level remained constant for the next 6 minutes and the machine was turned off. Over the next 8 minutes the $\infty$ level dropped off to 4 pqm. Instantaneous readings throughout the plant did not indicate excessive 00 exposures: maximum reading 12 ppm. 
Madical

Seventy-six questionnaires were completed. They were divided into a diesel exhaust-exposed group of 63 workers and a non diesel exhaust-exposed group of 13 workers based on whether they worked near a truck well or near a location where machinery $b=3$ been recently moved by diesel powered tiucks. We similarly aivided the interviewees into two groups based upon their assignment to Department 420, where methyl ethyl ketone (MFK) is used.

Symptoms were also analyzed in relation to self-reported exposure to any dust or chemicals. The workers were divided into three grours: those not reporting any exposures, those reporting exposure to diesel fumes (alone or in combination with other exposuzes), and those reporting only exposures other than diesel fumes. This method was also utilized for exposure to MEK and cutting and/or grinding operations.

\section{(a) Demographic and Medical History Data}

These groups were comparable (Table I-IV) with respect to age, sex, race, years employed at Pratt \& Witney, prevalence of self-repcrted chronic cough (cough on most days for at least three months out of the year), and emphysema or chronic bronchitis (defined as a physician's diagnosis of either condition).

Among the non-diesel area workel.s, there was a higher percentage of individuals reporting aliergies than among the diesel area workers but this difference was not statistically significant (Table I). Although the diesel area and the non-diesel area groups had identical percentages of smokers, ex-smokers and non-smokers, the diesel area group current smokers smoked significantly more than the non-diesel group (26.2 vs 13.3 pack years, Table I). This trend was also seen for ex-smokers (17 vs 9.2 pack years) but the difference is not statistically significant.

Among the workers in Department 420 as well as those reporting exposure to MEX, there were approximately 508 women (Table III) ; most groups tended to have 4 - 218 women. The Department 420 wrkers had a statistically significant difference in their smoking status distribution when compared to the non-Department 420 workers. They had no ex-smokers and a larger proportion of smokers and non-smokers.

Both MEX- and Cutting- and/or Grinding-exposed workers reported significantly higher prevalences of chronic cough than workers exposed to other substances or unexposed workers (Tables IV and V). 


\section{(b) Symptoms}

The diesel area workers had a greater percentage of respiratory symptoms, ans symotoms, and fatisise than the non-diesei area workers, although these differences were not statistically significant (Table VI). A significantly higher prevalence was also observed wien analyzed by reported exposure to diesel funes (Table VII).

Those individuals who work in Department 420 , where MEK is primarily used, had increased rates of cough, CNS symptons, and fatigue. These were significantly different tinan rates of these symptoms reported by non-Departmant 420 wrkers. Headache was reported twice as much in Department 420 than outside Department 120 but this difference was not statistically different (Table VIII). Then analyzed by reported exposure to Mrx, respiratory and CNS symptoms, headache and fatigue were reported significantly more than other exposure categories (Table IX).

When analyzer by reported exposure to cutting and/or grinding operations, irritative symptoms were the only symptoms witi a statisticaily significant difference (Table $X$ ).

\section{(c) OSHA 200 LOg}

A review of the five cases from departments that we investigated disclosed no cases that could be related to diesel fume exposure. One ase did involve nasal irritation and vertigo due to MER exposure in Department 420 .

\section{DISCussIon}

Diesel enissions appear to be associated with a higher prevalence of respiratory symptoms in exposed workers both when analyzed by work area and by reported exposure to diesel fumes. None of the other symptons have this consistency. These synptoms are consistent with other health hazard evaluations and are in agreement with the medical literature for acute symptoms from diesel exposure (1).

These differences cannot be explained by the greater percentage of non-diesel area worker's reporting a history of allergies, since this would, if anything, tend to produce more symptrms in the non-diesel area group.

These differences may, however, be explained in part, by the greater number of pack years smoked by current smokers. 


$$
\text { Page - } 8 \text { - }
$$

MEx exposure was associated with increases in CNS symptoms, heaciache and fatigue when aralyzed by both work area and reported exposures. These symptons are consistent with organic solvent. exposure and appear to bave resulted in one OSHA recordable illness in 1983. It should be noted that Department 420 was adjacent to truck wells 1 and 10, and many of these workers mentioned exposure to diesel fumes. This may have contributed to the increased prevaiense of cough and respiratory symotoms.

\section{Cokctusions}

Based on the results of this investigation, NIOSH has determined trat although $C O$ exposures were low at the time of our visit, the occurrence of respiratory symptoms among exposed employees indicates at least intermittent effects from exposure to diesel fumes, and steps should be taken to minimize these exposures. In addition, there was a relationship between reported MEK exposure and symptoms reported in Department 420.

\section{RECOYMENDATICIS}

1. Fop-starting or push-starting of ciesel trucks, although a prohibited practice, has beer, observed by eiployess, so, enforcement of plant rules should be more stringent. This was the largest single source of "blue fume" that employees complained about.

2. A concerted effort should be made to prevent funes from the truck wells from entering the general work areas. This could be accorplished by using strateglcally positioned exhaust fans in the truck wells. Also it may be advisable to keep the shop doors closed until the trucks are turned off.

3. Major machinery moving should be scheduled when occupancy is lowest to minimize exposures during this operation. It may be administraisively possible to remove soloyees from surrounding areas during the actual moving operations.

\section{REFERENCCAS}

1. Health Hezard Determination: Sanica Cruz Metropolitan Transit District, DHHS (NIOSH), Publication No. 81-388-1129

2. Criteria for a Recommended Stanrard... Occupational Exposure to Ketones, DHHS/NIOSH Publication No.78-173, 1978. 


$$
\text { Page - } 9 \text { - }
$$

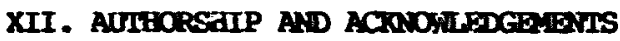

Beport Written By:

Nedical Sugport:

Originated by:
Kevin P. Mcklanus

Regional industrial Hygienist

IIOSH - Region 1

Boston, Massachusetts

John S. Norametz, M.S.

Hedical Officer

Hazard Evaluations and Technical Assistance Branch

Cincinnati, Ohio

Michael Donahue, $P_{c}$.

Medical Section

Hazard Evaluations and Technical Assistance Branch

Cincinnati, Ohio

Hazard Evaluations and Technical Assistance Branch

Division of Surveillance, Hazard Evaluations, and Field studies Cincinnati, Ohio 
Table I

Demographic and medical history data

$$
\begin{gathered}
\text { Pratt \& Whitney } \\
\text { East Hartford, Connecticut } \\
\text { HETA 84-089 }
\end{gathered}
$$

\begin{tabular}{|c|c|c|c|c|c|}
\hline \multicolumn{3}{|c|}{ Characteristic } & $\frac{\text { Non-Diesel }}{\text { Use Area }}$ & Diese 1 Use Area & $\begin{array}{l}\text { Two stded } \\
\text { Fisher's exact test }\end{array}$ \\
\hline \multicolumn{3}{|l|}{$\mathbf{N}$} & 13 & 63 & \\
\hline Age, $y$ & rs: & $\begin{array}{l}\text { Mean } \\
\text { (Range) }\end{array}$ & $\begin{array}{c}38 \\
(25-61)\end{array}$ & $\begin{array}{c}41 \\
(24-60)\end{array}$ & \\
\hline \multicolumn{3}{|c|}{$\begin{array}{c}\text { Duration of employment, } \\
\text { Mean } \\
\text { (Range) }\end{array}$} & $\begin{array}{l}\text { yrs: } \\
13.0 \\
(5.3-28.5)\end{array}$ & $\begin{array}{c}13.3 \\
(3.3-33.8)\end{array}$ & \\
\hline Race: & \multicolumn{2}{|c|}{$\begin{array}{l}\text { White (8) } \\
\text { Black } \\
\text { Hispanic } \\
\text { Asian }\end{array}$} & $\begin{array}{lr}9 & (69) \\
2 & (15) \\
1 & (8) \\
1 & (8)\end{array}$ & $\begin{array}{rr}48 & (76) \\
13 & (21) \\
1 & (2) \\
1 & (2)\end{array}$ & \\
\hline Sex: & \multicolumn{2}{|c|}{$\begin{array}{l}\text { Male } \\
\text { Female }\end{array}$} & $\begin{array}{rr}12 & (92) \\
1 & (8)\end{array}$ & $\begin{array}{l}53(84) \\
10(16)_{4}\end{array}$ & \\
\hline \multicolumn{3}{|c|}{ Chronic cough: } & $2(15)$ & $17(27)$ & $p=.50$ \\
\hline \multicolumn{3}{|c|}{$\begin{array}{l}\text { Chronic bronchitis } \\
\text { or emphysema }\end{array}$} & $2(15)$ & $5(8)$ & \\
\hline \multicolumn{3}{|c|}{ Allergies: } & $7(54)$ & $17(27)$ & $p=.10$ \\
\hline \multirow{3}{*}{\multicolumn{2}{|c|}{$\begin{array}{l}\text { Smoking: } \\
\text { Status: }\end{array}$}} & $\begin{array}{l}\text { Smoker } \\
\text { pack yrs } \\
\text { (Range) }\end{array}$ & $\begin{array}{l}5(38) \\
13.3(7-20)\end{array}$ & $\begin{array}{l}23(37) \\
26.2(3-100)\end{array}$ & $p=.01$ \\
\hline & & $\begin{array}{l}\text { Ex-smoker } \\
\text { pack yrs } \\
\text { (Range) }\end{array}$ & $9.2(23)$ & $\begin{array}{l}15(24) \\
17(1.5-60)\end{array}$ & $p=.51$ \\
\hline & & Non-smoker & $5(38)$ & $25(40)$ & \\
\hline
\end{tabular}

Diesel use area 
Table II

Demographic and medical history data

Pratt \& Whitney

East Hartford, Connecticut

HETA 84-089

\section{Diese 1 fume exposure}

No

Characteristic $\frac{\text { exposures }}{(n=11)}$
Other Diesel and exposures $(n=30)$ $\frac{\text { other exposures }}{(n=35)}$
Row by colum (3x2) Exact test

N

11

30

35

Age, yrs: Mean 43

(Range) (29-60)

$\stackrel{39}{(25-61)}$

40

(24-59)

Duration of employment, yrs Mean 18.8

(Range)

$(5.8-33.8)$

Race: White ( $(\xi)$

Black

Hispanic

Asian

8 (73)

3 (27)

0

o

$$
\text { Male }
$$

Fenale

$\begin{array}{rr}10 & (91) \\ 1 & (9)\end{array}$

0

Chronic cough:

1 (9)

$2(7)$

4 (11)

or emphy sema

2 (18)

11 (37)

$11(31)$

$p=.6$

A7tergies:

4 (36)

10 (33)

$14(40)$

Swoking: Smoker

Status: pack yrs

$23.6(12-45) \quad 23(3-54) .24 .7(5-100)$

(Range)

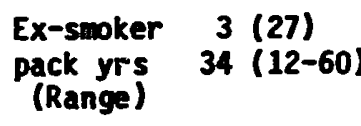

8 (27)

$10.1(.5-25)$

$7(20)$

pack yrs

Non-smoker 4 (36)

$12(40)$

$14(40)$ 
Table III

Demographic and medical history data

Pratt \& Whitney

East Hartford, Connecticut

HETA 84-089

MEK use area-Department 420

Not in

$\frac{\text { Characteristic }}{\text { Number of participants }} \frac{\text { Department } 420}{62}$

$\begin{array}{llcc}\text { Age, yrs: } & \text { Mean } & 40 & 42 \\ \text { (Range) } & (25-61) & (24-59)\end{array}$

Duration of employment, yrs

$$
\text { Mean }
$$

(Range)

Race: White

Black

Hispanic

Asian

Sex: Male

Female
14

(3-34)

49 (79)

, 9 (15)

2 (3)

2 (3)

59 (95)

3 (5)

Chronic bronchitis

or emphysema

Chronic cough:

Allergies:

Sinoking

Status:
$6(10)$

$13(21)$

$20(32)$

Smoker

pack yrs $24.5(3-100)$ pack yrs $15.7(.5-60)$

Non-smoker 23 (37)
Ex-smoker 18 (29) $\frac{\text { Department } 420}{14} \quad$ Fisher's exact test
Two sided

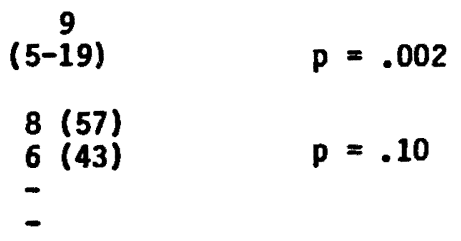

6 (43)

$8(57), p<.0001$

1 (7)

$6(43)$

$p=.10$
4 (29)

$7(50)$

$22.2(10-30)$

0

-

7 (50) 
Table IV

Demographic and medical history data

Pratt \& Hhitney

East Hartford, Connecticut

HETA 84-089

\section{MEK exposure}

\begin{tabular}{|c|c|c|c|c|c|}
\hline Characteristi & tic & $\begin{array}{l}\text { No } \\
\text { exposures }\end{array}$ & $\begin{array}{l}\text { Other } \\
\text { exposures }\end{array}$ & $\begin{array}{c}\text { MEK and } \\
\text { other exposures } \\
\end{array}$ & $\begin{array}{l}\text { Row by colum } \\
(3 \times 2) \text { Exact test }\end{array}$ \\
\hline $\begin{array}{l}\text { Number of } \\
\text { participant }\end{array}$ & & 11 & 48 & 17 & \\
\hline Age, yrs: & $\begin{array}{l}\text { Mean } \\
\text { (Range) }\end{array}$ & $\begin{array}{c}43 \\
(29-60)\end{array}$ & $\begin{array}{c}40 \\
(25-61)\end{array}$ & $\begin{array}{c}39 \\
(24-59)\end{array}$ & $\because$ \\
\hline
\end{tabular}

Duration of employment, yrs

$\begin{array}{lccc}\text { Mean } & 18.8 & 13.0 & 10.2 \\ \text { (Range) } & (5.8-33.8) & (3.3-32.4) & (5.4-18.5)\end{array}$

\begin{tabular}{|c|c|c|c|c|c|}
\hline Race: & $\begin{array}{l}\text { White (x) } \\
\text { Black } \\
\text { Hispanic } \\
\text { Asian }\end{array}$ & $\begin{array}{ll}8 & (73) \\
3 & (27) \\
0 & \\
0 & \end{array}$ & $\begin{aligned} 38 & (79) \\
6 & (12.5) \\
2 & (4) \\
2 & (4)\end{aligned}$ & $\begin{aligned} 11 & (65) \\
6 & (35) \\
0 & \\
0 & \end{aligned}$ & \\
\hline S & $\begin{array}{l}\text { Male } \\
\text { Female }\end{array}$ & $\begin{array}{rr}10 & (91) \\
1 & (9)\end{array}$ & $\begin{array}{rr}46 & (96) \\
2 & (4)\end{array}$ & $\begin{array}{l}9(53) \\
8(47)\end{array}$ & $p=.0003$ \\
\hline
\end{tabular}

Chronic cough: $\quad 0 \quad 12$ (25)

7 (41) $\quad p=.03$

Chronic bronchitis or emphysema

1 (9) $4(8) \quad 2(12)$

Allergies:

2 (18)

17 (35)

5 (29)

Smoking: Smoker

4 (36)

17 (35)

7 (41)

Status: $\begin{aligned} & \text { pack yrs } \\ & \text { (Range) }\end{aligned}$

$23.6(12-45) \quad 23.1(3-100) \quad 26.1(15-37.5)$

Ex-smoker $3(27)$
pack yrs
$34(12-60)$

13 (27)

(Range)

$12.4(.5-60)$

2 (12)

$9.5(7-12)$

Non-smoker 4 (36)

$18(37.5)$

$8(47)$ 


\section{Table V}

Demographic and medical history data

Pratt \& Whitney

East Hartford, Connecticut

HETA 84-089

\section{Cutting \& grinding exposure}

\begin{tabular}{|c|c|c|c|c|c|}
\hline \multicolumn{2}{|c|}{ Characteristic } & $\begin{array}{l}\text { No } \\
\text { eposures }\end{array}$ & $\begin{array}{l}\text { Other } \\
\text { exposures }\end{array}$ & $\begin{array}{l}\text { Cutting and/or } \\
\text { grinding and } \\
\text { other exposures }\end{array}$ & $\begin{array}{l}\text { Row by column } \\
(3 \times 2) \text { Exact test }\end{array}$ \\
\hline \multicolumn{2}{|c|}{$\begin{array}{l}\text { Number of } \\
\text { participants }\end{array}$} & 11 & 38 & 27 & \\
\hline $\begin{array}{l}\text { Age, yrs: } \\
\text { (Range) }\end{array}$ & Mean & $\begin{array}{c}43 \\
(29-60)\end{array}$ & $\begin{array}{c}40 \\
(24-59)\end{array}$ & $\begin{array}{c}39 \\
(25-61)\end{array}$ & \\
\hline \multicolumn{3}{|c|}{$\begin{array}{c}\text { Duration of employment, yrs } \\
\text { Mean } \\
\text { (Range) } \\
(5.8-33.8)\end{array}$} & $\begin{array}{l}11.4 \\
(3.3-32.4)\end{array}$ & $\begin{array}{c}13.6 \\
(4.5-28.5)\end{array}$ & \\
\hline \multicolumn{2}{|c|}{$\begin{array}{l}\text { Race: White (\%) } \\
\text { Black } \\
\text { Hispanic } \\
\text { Asian }\end{array}$} & $\begin{array}{l}8 \cdot(73) \\
3(27) \\
- \\
-\end{array}$ & $\begin{array}{rr}27 & (71) \\
8 & (21) \\
2 & (5) \\
1 & (3)\end{array}$ & $\begin{array}{rr}22 & (81) \\
4 & (15) \\
- & \\
1 & (4)\end{array}$ & \\
\hline \multicolumn{2}{|c|}{$\begin{array}{ll}\text { Sex: } & \text { Male } \\
& \text { Female }\end{array}$} & $\begin{array}{rr}10 & (91) \\
1 & (9)\end{array}$ & $\begin{array}{r}30(79) \\
8(21)\end{array}$ & $\begin{array}{r}25(93) \\
2 \quad(7)\end{array}$ & \\
\hline \multicolumn{2}{|c|}{ Chrunic cough: } & 0 & $9(24)$ & $10(37)$ & $p=.04$ \\
\hline \multicolumn{2}{|c|}{$\begin{array}{l}\text { Chronic bronchitis } \\
\text { or emphysema }\end{array}$} & $1(9)$ & $3(8)$ & $3(11)$ & \\
\hline \multicolumn{2}{|l|}{ Allergies: } & $2(18)$ & $12(32)$ & $10(37)$ & \\
\hline \multirow[t]{3}{*}{$\begin{array}{l}\text { Smoking: } \\
\text { Status: }\end{array}$} & $\begin{array}{l}\text { Smoker } \\
\text { pack yrs } \\
\text { (Range) }\end{array}$ & $\begin{array}{l}4(36) \\
23.6(12-45)\end{array}$ & $\begin{array}{l}14(37) \\
25.4(3-100)\end{array}$ & $\begin{array}{l}10(37) \\
22.1(5-54)\end{array}$ & \\
\hline & $\begin{array}{l}\text { Ex-smoker } \\
\text { pack yrs } \\
\text { (Range) }\end{array}$ & $\begin{aligned} & 3(27) \\
& 34(12-60)\end{aligned}$ & $\begin{aligned} 9 & (24) \\
15 & (3-60)\end{aligned}$ & $\begin{array}{l}6(22) \\
7.6(.5-22.5)\end{array}$ & \\
\hline & Non-smoker & - $4(36)$ & $15(39)$ & $11(41)$ & \\
\hline
\end{tabular}


Table VI

Reported symptoms by exposure area

Pratt \& Whitney

East Hartford, Connecticut

HETA 84-089

\section{Exposure Area}

\begin{tabular}{|c|c|c|c|}
\hline Symptom group & $\frac{\text { Non-Diese I }}{\text { Use Area }}$ & Diesel Use Area & $\begin{array}{c}\text { One sided } \\
\text { Fisher's exact test }\end{array}$ \\
\hline & $(N=13)$ & $(N=63)$ & \\
\hline Cough (1) & $2(158)$ & 12 (198) & \\
\hline Irritation(2) & $8(61)$ & $33(52)$ & \\
\hline Respiratory (3) & $2(15)$ & $22(35)$ & $p=.15$ \\
\hline Chest Pain & $1,(8)$ & $5 \quad(8)$ & \\
\hline CNS (4) & 1 (8) & $14(22)$ & $p=.21$ \\
\hline Nausea & $2(15)$ & $6(10)$ & \\
\hline Headache & $3(23)$ & $19(30)$ & \\
\hline Fatigue & 1 (8) & $13(21)$ & $p=.25$ \\
\hline
\end{tabular}

(1) Frequent cough or cough at night

(2) Eye irritation (burning, itchy, red or watery eyes), Nose irritation (burning, itchy or runny nose, or frequent sneezing)

(3) Difficulty breathing or shortness of breath, chest tightness, wheezing, or bringing up phiegm

(4) Drowsiness, dizziness or light headedness 
Table VII

Reported symptoms, by reported diese 1 exposure

Pratt \& Whitney

East Hartford, Connecticut

HETA 84-089

\section{Exposure group}

\begin{tabular}{|c|c|c|c|c|}
\hline Symptom group & $\frac{\text { No exposures }}{(N=11)}$ & $\frac{\text { Other exposures }}{(N=30)}$ & $\begin{array}{l}\text { Diese } 1 \text { and } \\
\frac{\text { other exposures }}{(N=35)}\end{array}$ & $\begin{array}{l}\text { Row by column } \\
(3 \times 2) \text { Exact test }\end{array}$ \\
\hline Cough & 0 & $5: 17)$ & $9(26)$ & $p=.17$ \\
\hline Irritation & $3(27)$ & $16(53)$ & $22(63)$ & $p=.12$ \\
\hline Respiratory & 0 & $10(33)$ & $14(40)$ & $p=.03$ \\
\hline Chest pain & $1(9)$ & $2(7)$ & 3 (9) & \\
\hline CHS & 0 , & $6(20)$ & $9(26)$ & \\
\hline Mausea & 0 & $4(13)$ & $4(11)$ & \\
\hline Headache & 0 & $13(43)$ & $9(26)$ & \\
\hline Fatigue & $1(9)$ & $5(17)$ & $8(23)$ & \\
\hline
\end{tabular}


Table VIII

Reported symptoms by exposure area

Pratt \& Whitney

East Hartford, Connecticut

HETA 84-089

\section{MEK Exposure Area}

Not in

Symptom group

Cough

Irritation

Respiratory

Chest Pain

CNS

Mausea

Headache

Fatigue
Department 420 $(N=62)$

$$
8 \text { (13) }
$$

32 (52)

17 (27)

5 (8)

, $6(10)$

5 (8)

$15(24)$

5 (8) $\frac{\text { Department } 420}{(N=14)}$

6 (42)

9 (64)

7 (50)

1 (7)

$9(64)$

3 (21)

7 (50)

$9(64)$
One sided

Fisher's exact test

$p=.02$

$p=.10$

$p<.0001$

$p=.16$

$p=.06$

$\mathrm{p}<.0001$ 
Ta'ble IX

Reported symptoms, by reported MEK exposure

\author{
Pratt \& Whitney \\ East Hartford, Connecticut \\ HETA 84-089
}

\title{
Exposure group
}

\begin{tabular}{|c|c|c|c|c|}
\hline Symptom group & $\frac{\text { No exposures }}{(N=11)}$ & $\frac{\text { 0ther exposures }}{(N=48)}$ & $\begin{array}{l}\text { MEK and } \\
\frac{\text { other exposures }}{(N=17)}\end{array}$ & $\begin{array}{l}\text { Row by column } \\
(3 \times 2) \text { Exact test }\end{array}$ \\
\hline Cough & 0 & $9(19)$ & $5(29)$ & $p=.16$ \\
\hline Irritation & $3(27)$ & $27(56)$ & $11(65)$ & $p=.15$ \\
\hline Respiratory & 0 & $15(31)$ & $9(53)$ & $p=.009$ \\
\hline Chest pain & 1 (9) & $3(6)$ & $2(12)$ & \\
\hline CNS & 0 & $6(13)$ & $9(53)$ & $p=.0006$ \\
\hline Nausea & 0 & $4 \quad(8)$ & $4(24)$ & $p=.14$ \\
\hline Headache & 0 & $12(25)$ & $10(59)$ & $p=.002$ \\
\hline Fatigue & 1 (9) & $4 \quad(8)$ & $+9(53)$ & $p=.0004$ \\
\hline
\end{tabular}




\section{Table $x$}

Reported symptoms, by reported exposure to cutting and/or grinding

Pratt \& Whitney

East Hartford, Connerticut

HETA 84-689

\section{Exposure group}

\begin{tabular}{|c|c|c|c|c|}
\hline Symptom group & $\frac{\text { No exposures }}{(N=11)}$ & $\frac{\text { Other exposures }}{(N=38)}$ & $\begin{array}{l}\text { Cutting and/or } \\
\text { grinding and } \\
\frac{\text { other exposures }}{(N=27)}\end{array}$ & $\begin{array}{l}\text { Row by colum } \\
(3 \times 2) \text { Exact test }\end{array}$ \\
\hline Cough & $\mathbf{0}$ & $8(21)$ & $6(22)$ & \\
\hline Irritation & $3(27)$ & $20(53)$ & $18(67)$ & $p=.08$ \\
\hline Respiratory & $\mathbf{0}$ & $14(37)$ & $10(37)$ & \\
\hline Chest pain & $1 \quad(9)$ & $2(5)$ & $3(11)$ & \\
\hline CNS & 0 & $11(29)$ & $4(15)$ & \\
\hline Nausea & 0 & $5(13)$ & $3(11)$ & \\
\hline Headache & $\mathbf{0}$ & $13(34)$ & $9(33)$ & \\
\hline Fatigue & $1(9)$ & $10(26)$ & $3(11)$ & \\
\hline
\end{tabular}

